\title{
RANCANG BANGUN APLIKASI $Q R$ CODE BERBASIS ANDROID PADA PERPUSTAKAAN AKADEMI KOMUNITAS NEGERI PUTRA SANG FAJAR BLITAR
}

\author{
M. Nur Fu'ad, M.Komı, Moch Kholil, S.Kom, M.T1, dan Shanti Ike Wardhani, S.A.B, M.Si3 \\ 1,2,3Akademi Komunitas Negeri Putra Sang Fajar Blitar \\ Jalan Tanjung No 1 Blitar Kode Pos 66121 \\ e-mail: .nurfuadmail@gmail.com,2moch.kholi189@gmail.com, 3bintangsiwa281292@gmail.com
}

\begin{abstract}
Abstrak - Perpustakaan bermanfaat untuk memajukan dan melestarikan kebudayaan serta merupakan fasilitas penting dalam keberhasilan proses pendidikan. Namun perpustakaan Akademi Komunitas Negeri Putra Sang Fajar Blitar belum tersistem sehingga pengelolaan dan pelayanan perpustakaan masih dilakukan secara manual dengan pencatatan transaksi peminjaman dan pengembalian secara tertulis. Dibutuhkan sistem peminjaman dan pengembalian yang tepat guna untuk meningkatkan pelayanan perpustakaan. Teknologi $Q R$ Code menjadi salah satu solusi dengan didukung sistem operasi Android, $Q R$ Code digunakan sebagai kode buku yang akan dicatat dalam transaksi peminjaman dan pengembalian. Uji coba aplikasi membuktikan bahwa transaksi peminjaman dan pengembalian dengan aplikasi QR Code perpustakaan lebih cepat daripada manual. Lama waktu rata-rata transaksi untuk 1, 3 dan 5 buku dengan aplikasi QR Code perpustakaan adalah 4,9 detik, 14,7 detik dan 23,2 detik.
\end{abstract}

Kata kunci: QR Code, Android, aplikasi perpustakaan

\begin{abstract}
The library is useful for promoting and preserving culture and becomes an important facility in the education process. But the library of Akademi Komunitas Negeri Putra Sang Fajar Blitar has not been systemized so that library management and services are still done manually by recording borrow and return transactions in writing. An appropriate borrows and returns system is needed to improve library services. QR Code technology is one of the solutions supported by Android operating system, OR Code is used as a book code that will be recorded in the borrows and returns transaction. Test of application prove that borrow and return transactions with the library QR Code application is faster than manual. Average transaction time for 1, 3 and 5 books are 4.9 seconds, 14.7 seconds and 23.2 seconds respectively.
\end{abstract}

Keywords: QR Code, Android, library application

\section{PENDAHULUAN}

Perpustakaan merupakan salah satu upaya untuk memajukan kebudayaan nasional dan sebagai wahana pelestarian kebudayaan bangsa. Dalam undang-undang no 43 tahun 2007 tentang perpustakaan [1] disebutkan bahwa "Perpustakaan adalah institusi pengelola koleksi karya tulis, karya cetak, dan/atau karya rekam secara profesional dengan sistem yang baku guna memenuhi kebutuhan pendidikan, penelitian, pelestarian, informasi, dan rekreasi para pemustaka". Perpustakaan juga merupakan fasilitas tak terpisahkan untuk menunjang keberhasilan proses pendidikan.

Akademi Komunitas Negeri Putra Sang Fajar Blitar sebagai perguruan tinggi tentunya juga membutuhkan perpustakaan sebagai sumber referensi dan literasi. Namun pelayanan perpustakaan Akademi Komunitas Negeri Putra Sang Fajar Blitar masih memiliki banyak kekurangan. Pelayanan perpustakaan masih dilaksanakan secara konvensional yakni dalam melayani proses peminjaman dan pengembalian buku masih menggunakan penulisan manual pada print out tabel transaksi yang disediakan. Selanjutnya peminjam harus membubuhkan tanda tangan pada kolom tanda tangan peminjaman. Sedangkan untuk pengembalian, dilakukan dengan menandatangi kolom tanda tangan pengembalian pada tabel transaksi yang sama. Tabel transaksi yang digunakan dalam pelayanan perpustakaan pada Akademi Komunitas Negeri Putra Sang Fajar Blitar ditunjukkan dalam Tabel 1.

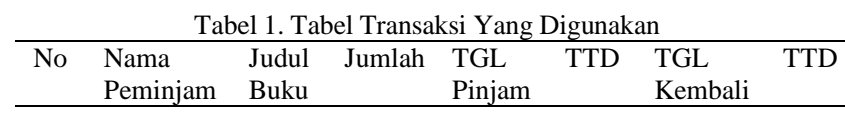

Dengan keadaan transaksi peminjaman dan pengembalian yang hanya ditulis pada print out tabel transaksi, petugas perpustakaan menjadi kesulitan untuk mengontrol sirkulasi peminjaman dan pengembalian. Hal 
tersebut dikarenakan untuk mengetahui transaksi peminjaman buku, petugas harus mengecek tiap lembar print out tabel transaksi. Sedangkan dalam transaksi pengembalian, terkadang peminjam sudah menandatangi kolom pengembalian ketika meminjam, sehingga data pengembalian menjadi tidak valid.

Dengan kondisi tersebut, dibutuhkan sistem peminjaman dan pengembalian yang tepat guna untuk meningkatkan pelayanan perpustakaan. Teknologi $Q R$ Code menjadi salah satu solusi untuk meningkatkan pelayanan perpustakaan karena mampu mencatat data dalam waktu yang cepat. Dengan didukung oleh perkembangan sistem operasi Android, QR Code dapat digunakan sebagai kode buku yang akan dicatat dalam transaksi peminjaman dan pengembalian. Dengan penggunaan teknologi ini, nantinya peminjaman tidak lagi dilakukan dengan menulis dalam print out tabel transaksi, sehingga pencatatan transaksi peminjaman dan pengembalian lebih lebih valid dan aman.

PG Naik et all [2] melakukan penelitian terkait perancangan dan pembuatan sistem terintegrasi untuk akses cepat ke sumber daya perpustakaan dari lokasi mana saja kapan saja dengan menggunakan pemindai $Q R$ Code. Kemudian Rahaman [3] melakukan penelitian dalam meningkatkan pelayanan perpustakaan dengan membandingkan penggunaan Barcode, $Q R$ Code dan Rfid pada Central Library National Institute Of Technology, Rourkela. Pada penelitian tersebut $Q R$ Code unggul dari segi penghematan biaya dan kecepatan. Parabhoi et all [4] mengaplikasikan penggunaan $Q R$ Code pada perpustakaan yang mempermudah user dalam mengakses sebagian besar informasi perpustakaan.

Berdasarkan penjelasan di atas, peneliti berinisiatif untuk melakukan perancangan aplikasi $Q R$ Code berbasis Android pada perpustakaan. Diharapkan penelitian ini dapat digunakan untuk mengembangkan aplikasi perpustakaan sehingga dapat meningkatkan pelayanan perpustakaan di Akademi Komunitas Negeri Putra Sang Fajar Blitar.

\section{STUDI PUSTAKA}

\section{A. Perpustakaan}

Perpustakaan merupakan upaya untuk memelihara dan meningkatkan efisiensi dan efektifitas proses belajarmengajar. Perpustakaan yang terorganisasi secara baik dan sistematis, secara langsung atau pun tidak langsung dapat memberikan kemudahan bagi proses belajar mengajar di sekolah tempat perpustakaan tersebut berada. Hal ini, terkait dengan kemajuan bidang pendidikan dan dengan adanya perbaikan metode belajar-mengajar yang dirasakan tidak bisa dipisahkan dari masalah penyediaan fasilitas dan sarana pendidikan [5].

Tujuan perpustakaan menurut Suherlan [6] adalah untuk membantu masyarakat dalam segala umur dengan memberikan kesempatan dengan dorongan melalui jasa pelayanan perpustakaan agar mereka:

- dapat mendidik dirinya sendiri secara berkesimbungan

- dapat tanggap dalam kemajuan pada berbagai lapangan ilmu pengetahuan, kehidupan sosial dan politik

- dapat memelihara kemerdekaan berfikir yang konstruktif untuk menjadi anggota keluarga dan masyarakat yang lebih baik

- dapat mengembangkan kemampuan berfikir kreatif, membina rohani dan dapat menggunakan kemempuannya untuk dapat menghargai hasil seni dan budaya manusia

- dapat meningkatkan taraf kehidupan sehari-hari dan lapangan pekerjaannya

- dapat menjadi warga negara yang baik dan dapat berpartisipasi secara aktif dalam pembangunan nasional dan dalam membina saling pengertian antar bangsa

- dapat menggunakan waktu senggang dengan baik yang bermanfaat bagi kehidupan pribadi dan sosial.

\section{B. QR Code}

QR Code merupakan singkatan dari Quick Response Code, atau bisa diartikan sebagai kode dengan respon yang cepat. $Q R$ Code adalah barkode 2 dimensi (Gambar 1) dan dapat dengan mudah dibaca melalui software pembaca $Q R$ Code. $Q R$ Code sebenarnya diciptakan sebagai pengembangan dari aplikasi bar code Jepang. $Q R$ Code pertama kali diperkenalkan pada tahun 1994 oleh Denson Wave yang merupakan anak perusahaan Toyota Motors [4].

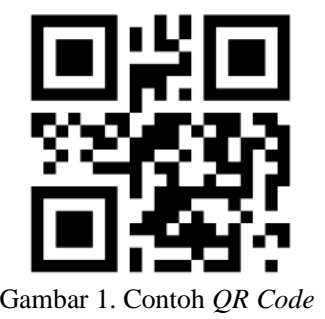

$Q R$ Code dapat dengan mudah dibaca melalui device yang memiliki fasilitas pembaca $Q R$ Code seperti smartphone. $Q R$ Code dapat memberi perintah kepada smartphone untuk melaksanakan aksi sesuai dengan hasil ekripsi teks yang terkandung dalam $Q R$ Code. Kode dalam $Q R$ Code dapat menyajikan link yang langsung terhubung pada URL, atau juga dapat menyajikan vCard (yang langsung tersimpan pada smartphone), atau melakukan panggilan panggilan telepon ke nomor tertentu, mengirim SMS maupun e-mail [4].

$Q R$ Code menyimpan data dalam jumlah besar dan dapat digunakan di mana saja [3]. $Q R$ Code memiliki kapasitas untuk menyimpan data yang cukup besar. Untuk karakter numeric kapasitasnya mencapai 7089 karakter, untuk alphanumeric 4296 karakter, untuk biner 2953 bytes, sedangkan untuk kanji 1817 karakter. Keterangan kapasitas QR Code ditampilkan dalam Tabel 2.

\begin{tabular}{ccc} 
& \multicolumn{2}{c}{ Tabel 2. Kapasitas $Q R$ Code [7] } \\
\hline Format & Kapasitas Data & Karakter \\
\hline Numerk & 7089 Karakter & $0-9$ \\
Alfanumerik & 4296 Karakter & $0-9$ A-Z (upper-case) space \$ \\
& & $*+-, /$ : \\
Biner & 2953 bytes & $\begin{array}{c}\text { Default encoding: ISO 8859-1 } \\
\text { (QR Code 2005) }\end{array}$ \\
Kanji & 1817 Karakter & Shift JIS X 0208 \\
\hline
\end{tabular}

\section{Android}

Android adalah software open source dan sistem operasi berbasis Linux untuk mobile device seperti pada smartphone dan computer tablet. Android dikembangkan oleh aliansi Open Handset yang dipimpin oleh Google dan perusahaan lainnya. Meskipun device Android baru mulai tersedia mulai 
Oktober 2008, saat ini lebih dari satu milyar device Android telah beredar, dan jumlah tersebut terus bertambah setiap harinya [8]. Hanya dalam beberapa tahun, Android telah menghasilkan dampak yang luar biasa.

Device Android telah didukung dengan hardware yang sangat menunjang kebutuhan kehidupan modern. Beberapa hardware tersebut ditampilkan dalam Tabel 3. Pada tabel tersebut menampilkan beberapa fitur hardware, diantaranya yaitu Accelerometer, Radio Bluetooth, Compass, Camera dan GPS Receiver. Masing-masing hardware tersebut memiliki kegunaan yang sangat mambantu pengguna dalam berbagai macam keperluan. Selain itu, device Android juga dilengkapi dengan layar sentuh (touchscreen) yang memungkinkan penggunanya mengoperasikan smartphone tanpa tombol, juga didukung hardware penyimpanan dalam bentuk SD Card maupun hardisk internal dan berbagai hardware canggih lainnya.

Tabel 3. Hardware Device Android [8]

\begin{tabular}{cc}
\hline Hardware & Kegunaan \\
\hline Accelerometer & $\begin{array}{c}\text { Sebagai indikator pergerakan } \\
\text { smartphone }\end{array}$ \\
Radio bluetooth & Sebagai indikator koneksi headset \\
Compass & $\begin{array}{c}\text { Sebagai indicator arah yang dituju user } \\
\text { Untuk mengambil gambar (memfoto) } \\
\text { Camera }\end{array}$ \\
GPS Receiver & Sebagai indikator lokasi smartphone \\
\hline
\end{tabular}

\section{METODE}

\section{A. Objek Penelitian}

Penelitian ini berfokus untuk mengembangkan aplikasi QR Code perpustakaan yang dapat digunakan untuk melakukan transaksi peminjaman maupun pengembalian buku perpustakaan. Transaksi peminjaman dan pengembalian buku sangat penting dalam operasional perpustakaan.

\section{B. Alur Peminjaman}

Alur peminjaman pada perpustakaan Akademi Komunitas Negeri Putra Sang Fajar Blitar sebelumnya masih menggunakan sistem manual yang mengharuskan peminjam untuk mencatat pada form peminjaman. Berikut adalah alur peminjaman buku perpustakaan tanpa menggunakan aplikasi QR Code perpustakaan :

1. Peminjam datang ke perpustakaan

2. Peminjam melakukan pencarian buku

3. Peminjam melakukan pencataan di form peminjaman

4. Petugas memberikan persetujuan peminjaman di form peminjaman

5. Peminjam boleh membawa buku tersebut keluar perpustakaan untuk dipinjam.

Alur peminjaman buku perpustakaan dengan rancangan aplikasi $Q R$ Code perpustakaan dilakukan dengan cukup menscan $Q R$ Code yang terdapat pada buku dengan sistem yang dirancang. Berikut adalah alur peminjaman buku perpustakaan dengan menggunakan aplikasi $Q R$ Code perpustakaan :
1. Peminjam datang ke perpustakaan

2. Peminjam melakukan pencarian buku

3. Peminjam melakukan scan pada buku yang akan dipinjam

4. Petugas akan memberikan persetujuan peminjaman menggunakan aplikasi

5. Peminjam boleh membawa buku tersebut keluar perpustakaan untuk dipinjam.

C. Alur Pengembalian

Alur pengembalian buku pada perpustakaan Akademi Komunitas Negeri Putra Sang Fajar Blitar sebelumnya juga masih menggunakan sistem manual yang mengharuskan peminjam untuk memberikan catatan pengembalian dan tanda tangan pada form peminjaman di kolom pengembalian. Berikut adalah alur pengembalian buku perpustakaan tanpa menggunakan aplikasi $Q R$ Code perpustakaan :

1. Peminjam membawa buku yang akan dikembalikan ke perpustakaan.

2. Peminjam melakukan pencarian pada form peminjaman terhadap transaksi peminjaman yang dilakukannya.

3. Peminjam mencatat pengembalian pada kolom pengembalian di form peminjaman.

4. Petugas memberikan persetujuan pengembalian pada kolom pengembalian di form peminjaman

Alur pengembalian buku perpustakaan dengan rancangan aplikasi $Q R$ Code perpustakaan dilaksanakan dengan melakukan konfirmasi pengembalian pada sistem yang dirancang setelah sebelumnya mengembalikan buku terlebih dahulu. Berikut adalah alur pengembalian buku perpustakaan dengan menggunakan aplikasi $Q R$ Code perpustakaan :

1. Peminjam membawa buku yang akan dikembalikan ke perpustakaan.

2. Peminjam melakukan permohonan persetujuan pengembalian menggunakan aplikasi.

3. Petugas memberikan persetujuan pengembalian dengan cara melakukan scan pada buku yang dikembalikan menggunakan aplikasi.

\section{Metode Pengembangan Sistem}

Penelitian ini menggunakan metode pengembangan sistem model waterfall. Model waterfall terdiri dari beberapa tahap, dan setiap tahap harus dilalui untuk dapat menuju tahap selanjutnya seperti pada Gambar 2. Tahap dari model waterfall memiliki 5 tahap yakni, requirement, design, implementation, verification dan maintenance. 




Gambar 2. Metode pengembangan sistem model waterfall

Berikut penjelasan dari masing-masing tahap dalam metode pengembangan sistem model waterfall menurut Buchori et al [9] :

1. Requirement, tahap ini fokus pada identifikasi kebutuhan perangkat lunak. Untuk mengetahui sifat program yang akan dibuat, domain informasi perangkat lunak harus benar-benar difahami.

2. Design, tahap ini digunakan untuk mengubah hasil identifikasi kebutuhan menjadi representasi dalam bentuk desain "blueprint" perangkat lunak sebelum proses implementasi kode dimulai. Hasil desain harus dapat mengimplementasikan identifikasi kebutuhan yang disebutkan pada tahap sebelumnya.

3. Implementation, tahap ini digunakan untuk menterjemahkan hasil desain perangkat lunak agar dapat dipahami oleh komputer sebagai perangkat keras. Cara yang dilakukan yaitu melalui bahasa pemrograman dengan proses pengkodean.

4. Verification, tahap ini digunakan untuk menguji hasil pengkodean perangkat lunak dan jika semua fungsi sudah berjalan, perangkat lunak akan digunakan sesrara resmi. Semua fungsi perangkat lunak harus diuji, sehingga perangkat lunak bebas dari kesalahan dan hasilnya harus benar-benar sesuai dengan kebutuhan yang telah ditetapkan sebelumnya.

5. Maintenance, pada tahap ini perangkat lunak sudah digunakan dan perlu dilakukan perawatan maupun pengembangan secara rutin. Ini diperlukan karena perangkat lunak yang dibuat kadang ada kesalahan maupun untuk memenuhi kebutuhan pengguna yang dinamis. Saat dijalankan, mungkin masih ada beberapa kesalahan kecil yang tidak ditemukan sebelumnya, atau jika ada peningkatan kebutuhan fitur tambahan yang tidak ada dalam perangkat lunak sebelumnya.

\section{HASIL DAN PEMBAHASAN}

\section{A. Alur Aplikasi}

Pada penelitian ini dihasilkan 3 alur utama, yakni alur saat user membuka aplikasi, alur saat user melakukan scan $Q R$ Code dan alur peminjaman dan pengembalian buku. Alur yang dibuat digambarkan menggunakan flowchart. Alur saat user membuka aplikasi yaitu memasukkan user id ke sistem, kemudian sistem akan mengecek riwayat peminjaman user. Sistem akan mengecek apakah buku yang dipinjam lebih dari 2 dan mengecek apakah buku yang telah dipinjam terlambat dikembalikan, jika ya maka sistem akan memberikan notifikasi bahwa user tidak boleh meminjam buku dan jika tidak akan ada notifikasi bahwa user boleh meminjam buku.
Alur saat user membuka aplikasi digambarkan pada Gambar 3.

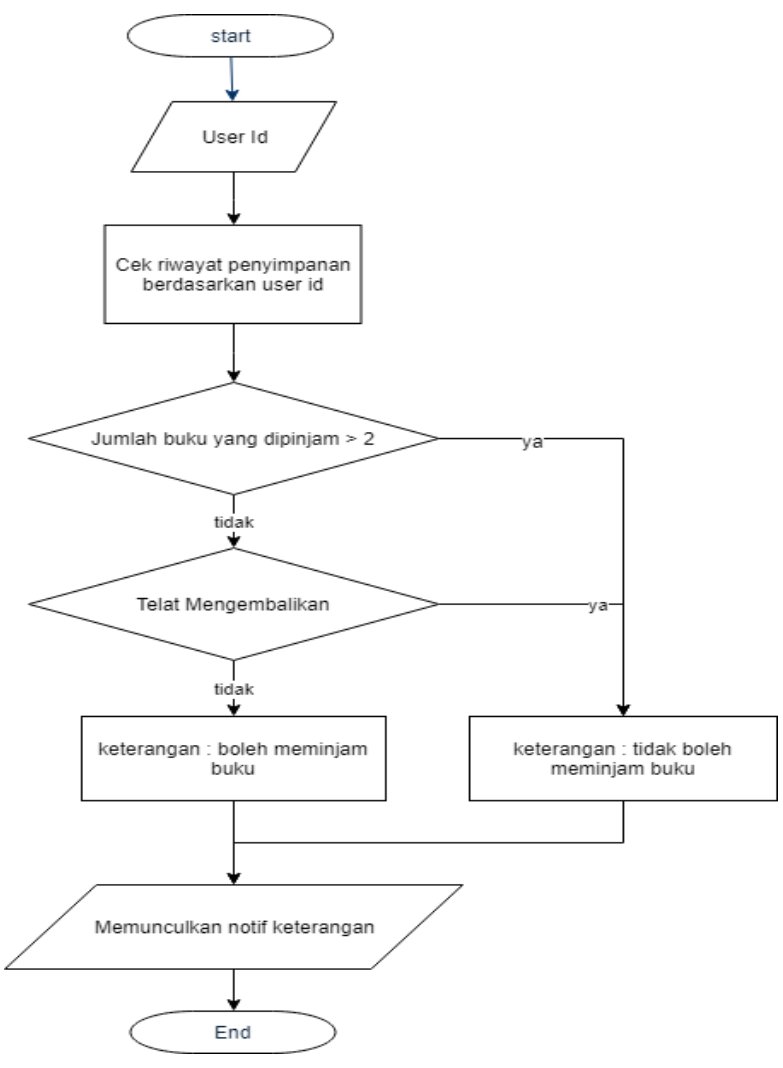

Gambar 3. Flowchart user membuka aplikasi

Alur saat user melakukan scan QR Code yang terdapat di masing-masing buku yakni, setelah user melakukan scan $Q R$ Code maka sistem akan menterjemahkan $Q R$ Code menjadi kode buku yang akan dipinjam. Kemudian kode buku dan user id yang meminjam buku akan disimpan ke sistem. Selanjutnya sistem akan memunculkan notifikasi bahwa buku terpinjam. Alur saat user melakukan scan QR Code digambarkan pada Gambar 4.

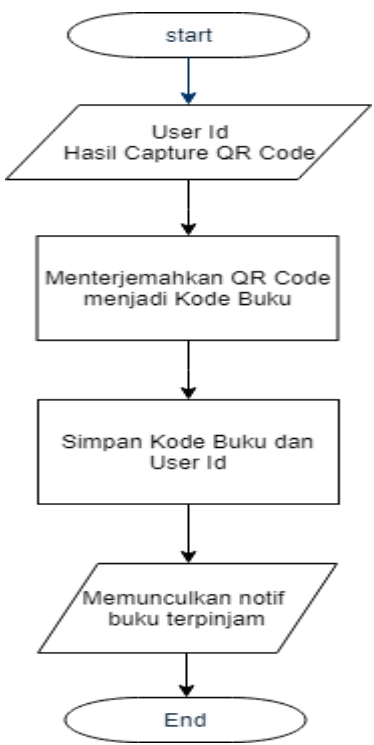

Gambar 4. Flowchart user scan buku 
Alur peminjaman dan pengembalian buku yakni, petugas melakukan scan $Q R$ Code buku, sistem akan menterjemahkan hasilnya menjadi kode buku dan sistem akan melakukan proses transaksi peminjaman atau pengembalian. Untuk peminjaman, setelah dilakukan scan pada buku oleh petugas, sistem akan mengecek apakah buku sudah dipinjam atau belum, jika belum buku dikembalikan ke user untuk dilakukan proses scan peminjaman. Setelah user melakukan scan peminjaman, petugas akan memperbolehkan user membawa buku yang dipinjam.

Sedangkan untuk pengembalian, setelah petugas melakukan scan pada buku, sistem akan mengecek apakah buku telat dikembalikan atau tidak. Jika terlambat, maka akan memunculkan notifikasi keterlambatan dan akan mendapatkan sanksi sesuai aturan perpustakaan, namun jika buku tidak telambat dikembalikan maka akan ada pilihan apakah akan dikembalikan atau peminjaman diperpanjang. Proses peminjaman dan pengembalian buku diakhiri dengan memunculkan notifikasi keterangan di sistem. Alur peminjaman dan pengembalian buku digambarkan pada Gambar 5

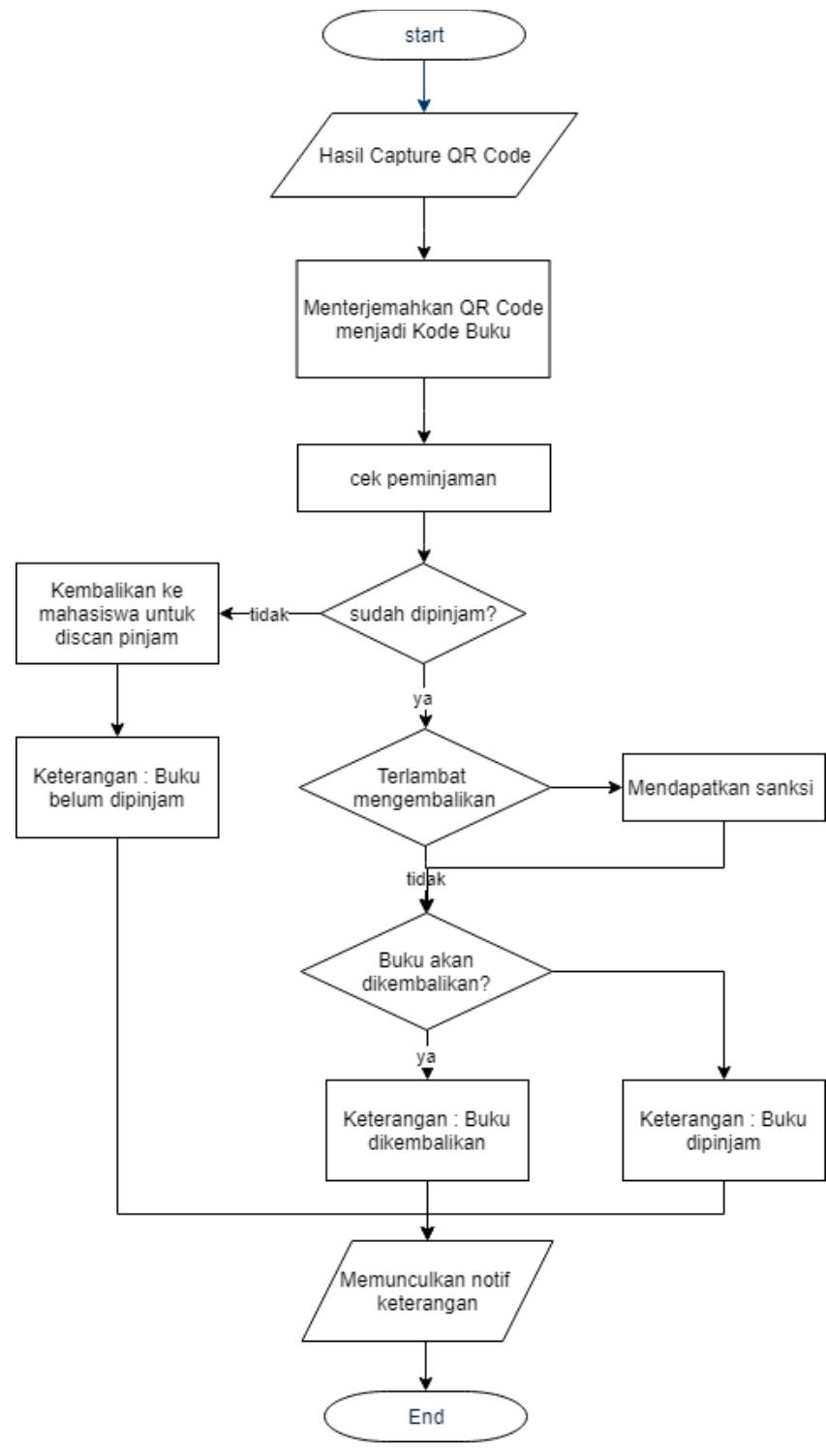

Gambar 5. Flowchart peminjaman dan pengembalian buku

\section{B. Basis Data Aplikasi}

Pada sistem ini, digunakan basis data yang terdiri dari 4 tabel, yakni tabel buku, tabel user, tabel transaksi peminjaman dan tabel transaksi pengembalian. Pada tabel buku terdiri dari kode buku, judul buku, pengarang, penerbit dan tahun terbit. Pada tabel user, terdapat kode user, nama, password, nomer telepon dan keterangan. Pada tabel transaksi peminjaman, terdapat kode transaksi pinjam, kode buku yang dipinjam, kode petugas, tanggal pinjam dan keterangan. Untuk tabel transaksi pengembalian terdapat kode transaksi pengembalian, kode buku, kode petugas, tanggal kembali dan kode transaksi pinjam. Adapun hubungan antara tabel buku, tabel user, tabel transaksi peminjaman dan tabel transaksi pengembalian ditampilkan dalam Gambar 6.

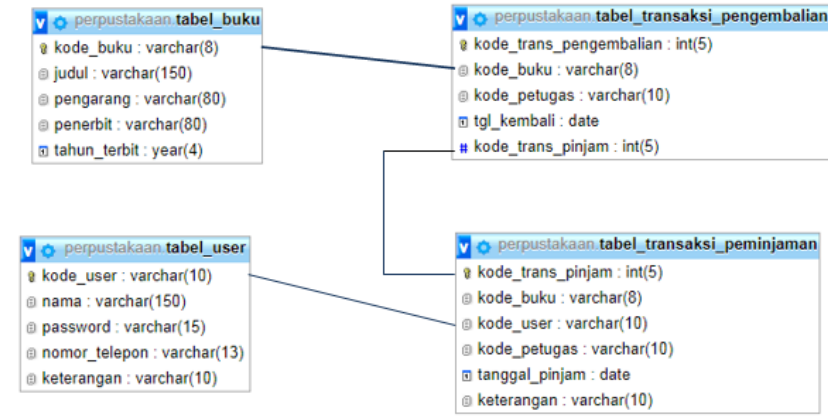

Gambar 6. Hubungan antar tabel dalam aplikasi $Q R$ Code perpustakaan

\section{Hasil Tampilan Aplikasi}

Hasil tampilan aplikasi berisi tampilan antar muka sesuai dengan rancangan aplikasi. Adapun untuk $Q R$ Code yang digunakan yakni $Q R$ Code yang ditengahnya ditambahkan logo Akademi Komunitas Negeri Putra Sang Fajar Blitar seperti pada Gambar 7. QR Code yang digunakan berisi kode buku yang mewakili identitas buku dalam basis data.

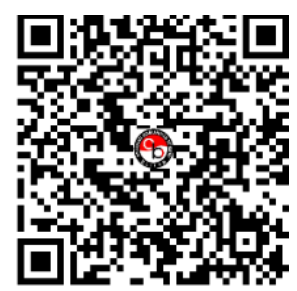

Gambar 7. QR Code yang digunakan

Halaman pertama ketika membuka aplikasi adalah halaman login yang digunakan untuk masuk ke dalam aplikasi. Halaman login ditampilkan pada Gambar 7. Setelah proses authentikasi login dilakukan, akan terdapat dua jenis user, pertama Peminjam dan kedua Petugas. Peminjam hanya dapat melakukan transaksi peminjaman dan permohonan pengembalian. Sedangkan petugas dapat melakukan perrsetujuan peminjaman dan persetujuan pengembalian.

Halaman kedua yakni halaman utama aplikasi $Q R$ Code yang ditampilkan pada Gambar 8. Pada halaman utama, terdaapat menu utama terkait peminjaman, pengembalian, histori peminjaman dan hubungi petugas. Pada halaman ini Peminjam dapat menuju ke transaksi peminjaman maupun menuju permohonan pengembalian. 

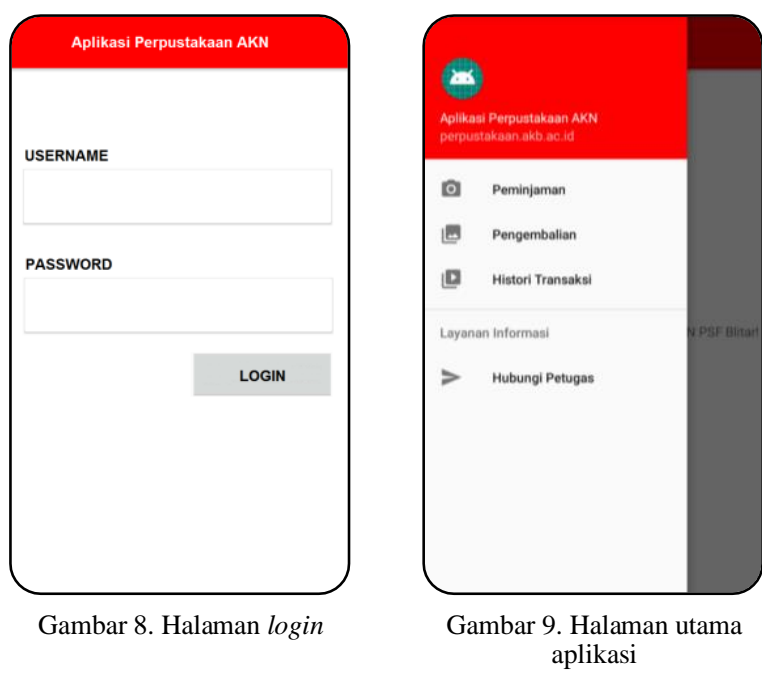

Halaman ketiga yakni halaman transaksi peminjaman yang dilakukan oleh user, pada halaman ini user diarahkan ke halaman scan $Q R$ Code dengan menekan tombol scan untuk melakukan scan pada $Q R$ Code buku sebelum dapat meminjam buku. Buku yang dipinjam harus discan terlebih dahulu sebelum dapat dipinjam. Halaman transaksi peminjaman ditampilkan dalam Gambar 10.

Selanjutnya user akan masuk ke halaman keempat yakni halaman scan $Q R$ Code. Pada halaman ini aplikasi akan secara otomatis menterjemahkan $Q R$ Code, sedangkan Peminjam bertugas untuk mengarahkan ke $Q R$ Code yang akan discan. Halaman scan $Q R$ Code ini ditampilkan pada Gambar 11.

Setelah proses scan selesai, akan aplikasi akan dikembalikan secara otomatis ke halaman transaksi peminjaman yang telah terisi (Gambar 12). Pada halaman ini, data buku akan secara otomatis terisi berdasarkan $Q R$ Code buku yang telah di scan. Dengan demikian user tidak perlu mengisi data buku, tinggal melakukan scan $Q R$ Code pada buku dan data buku akan secara otomatis masuk ke dalam aplikasi. Selanjutnya user menekan tombol pinjam dan menunggu petugas untuk menyetujui peminjaman.

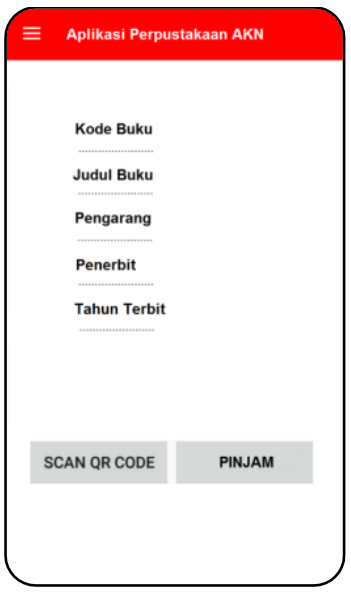

Gambar 10. Halaman transaksi peminjaman (USER)

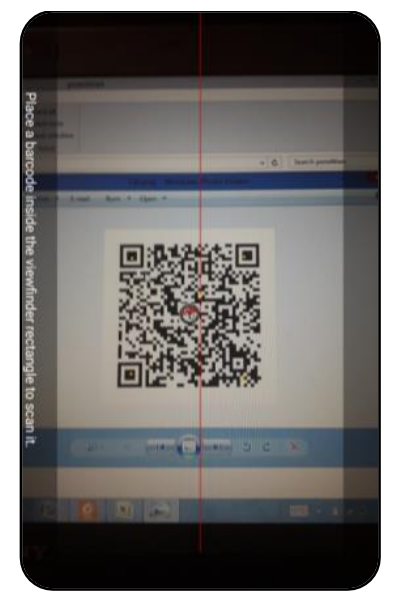

Gambar 11. Halaman scan $Q R$ Code (USER)

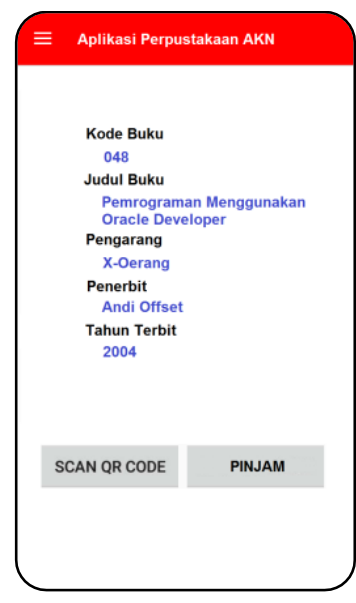

Gambar 12. Halaman transaksi peminjaman yang telah terisi (USER)

Selanjutnya beralih ke halaman yang ditampilkan untuk petugas. Pada halaman persetujuan peminjaman petugas, petugas dapat melakukan pengecekan identitas user, kode buku yang akan dipinjam dan tanggungan pengembalian buku yang belum dikembalikan oleh user. Jika terdapat tanggungan buku, maka petugas dapat menolak peminjaman buku yang diajukan. Sedangkan jika sudah tidak ada tanggungan, maka petugas dapat menyetujui peminjaman buku. Setelah persetujuan dilakukan maka akan muncul halaman proses peminjaman berhasil. Halaman persetujuan peminjaman oleh petugas ditampilkan pada Gambar 13 sedangkan halaman proses peminjaman berhasil ditampilkan pada Gambar 14.
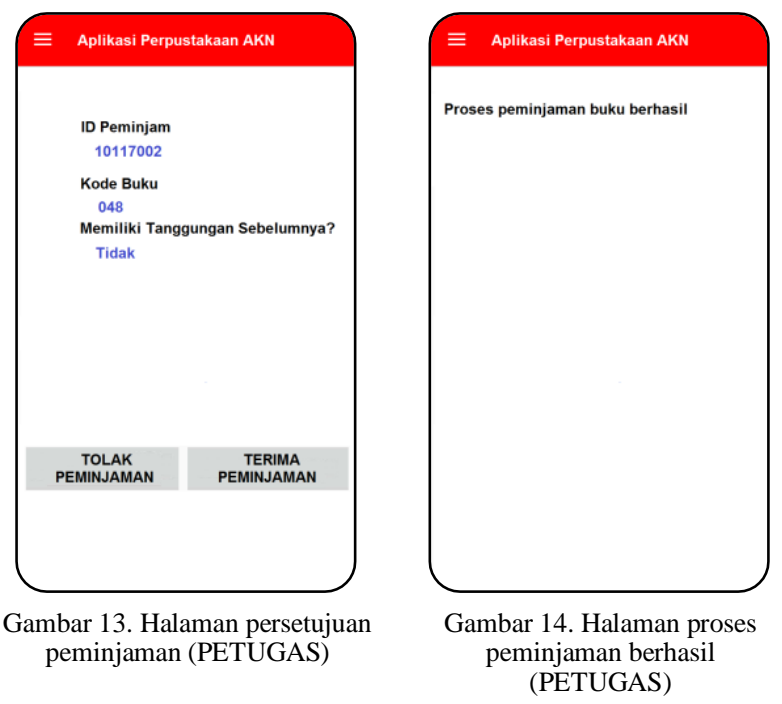

Pada proses ini, peminjaman telah selesai dan user boleh membawa buku keluar perpustakaan untuk dipinjam. Selanjutnya untuk pengembalian, user datang ke perpustakaan membawa buku yang akan dikembalikan. Untuk pengembalian user membuka halaman pengembalian dan melakukan permohonan pengembalian buku dengan menekan menu pengembalian.

Setelah itu akan muncul halaman menunggu pengembalian, pada halaman ini user harus menunggu Petugas untuk menyetujui pengembalian buku. Ketika petugas selesai melakukan persetujuan maka akan muncul halaman proses pengembalian berhasil. Halaman setelah menu pengembalian ditampilkan dalam Gambar 15, 
sedangkan halaman proses pengembalian sukses ditampilkan dalam Gambar 16 .
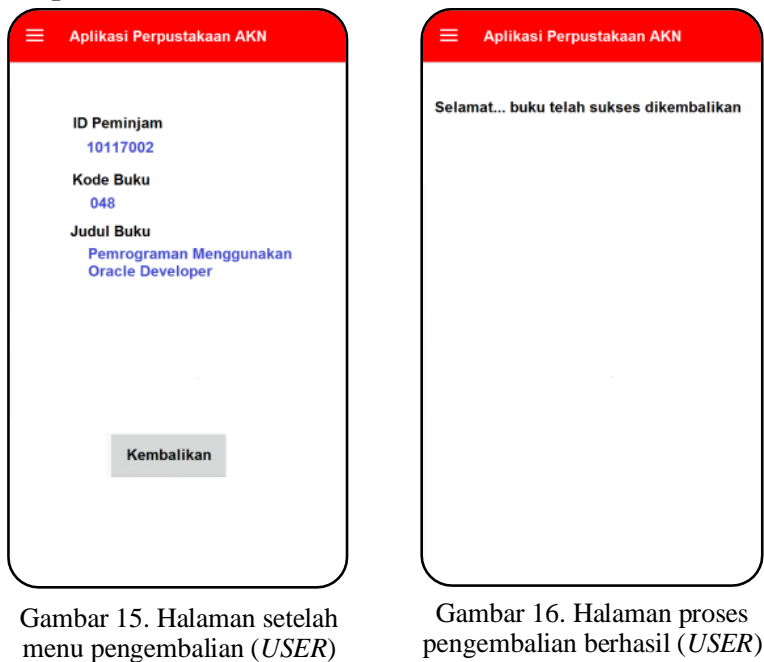

Selanjutnya beralih ke proses yang pengembalian yang melibatkan petugas. Setelah user melakukan permohonan pengembalian, pada halaman pemberitahuan pengembalian petugas akan muncul pemberitahuan pengembalian buku. Kemudian persetujuan pengembalian dilakukan oleh petugas dengan menekan tombol scan buku. Setelah itu halaman akan otomatis beralih ke halaman scan pengembalian.

Pada halaman scan pengembalian, petugas bertugas untuk mengarahkan scanner ke $Q R$ Code buku. Aplikasi akan secara otomatis menterjemahkan $Q R$ Code dan menyimpan data hasil scan. Setelah proses scan selesai, maka akan muncul halaman hasil scan pengembalian. Jika pengembalian buku berhasil, maka akan muncul konfirmasi bahwa pengembalian buku berhasil beserta data buku yang dikembalikan. Proses ini mengakhiri proses pengembalian. Halaman pemberitahuan pengembalian ditampilkan pada Gambar 17, sedangkan halaman hasil scan pengembalian ditampilkan pada Gambar 18.

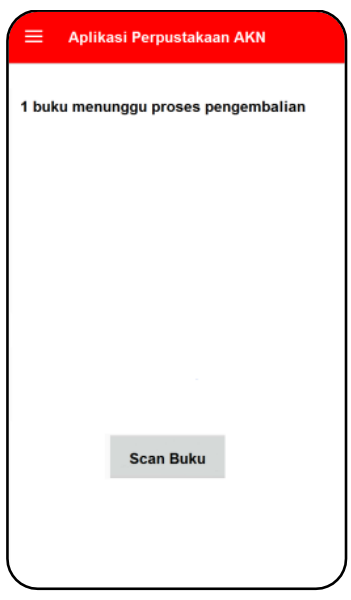

Gambar 17. Halaman pemberitahuan pengembalian (PETUGAS)

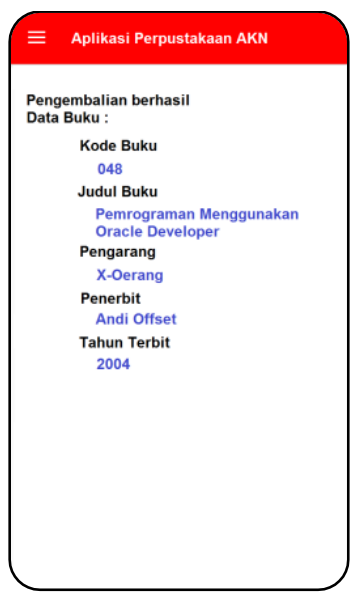

Gambar 18. Halaman hasil scan pengembalian (PETUGAS)

\section{Uji Coba Aplikasi}

Dalam uji coba aplikasi diberikan indikator lama waktu transaksi. Digunakan perbandingan dari lama waktu transaksi menggunakan $Q R$ Code dan tanpa $Q R$ Code (manual). Data lama waktu pencatatan diperoleh menggunakan kuisioner terhadap user. Kuisioner dilakukan dengan cara melakukan pencatatan data transaksi peminjaman dan pengembalian untuk buku yang sama dalam bentuk tulisan (manual) dan aplikasi scan QR Code. User diminta untuk menulis data buku yang dibutuhkan dalam transaksi peminjaman dan pengembalian dan melakukan scan $Q R$ Code untuk transaksi peminjaman dan pengembalian. Lama waktu kemudian dicatat. Selanjutnya diambil nilai rata-rata yang ditampilkan dalam tabel 4 .

Tabel 3. Hardware Device Android (Burton, 2015)

\begin{tabular}{lll}
\hline \multirow{2}{*}{ Jumlah buku } & \multicolumn{2}{c}{ Rata-rata Waktu } \\
\cline { 2 - 3 } & Dengan $Q R$ Code & Manual \\
\hline 1 buku & 4,9 detik & 37,1 detik \\
3 buku & 14,7 detik & 1 menit 53,4 detik \\
5 buku & 23,2 detik & 3 menit 43,4 detik \\
\hline
\end{tabular}

Berdasarkan Tabel 4.1, diperoleh data bahwa rata-rata waktu transaksi untuk 1 buku dengan aplikasi $Q R$ Code perpustakaan adalah 4,9 detik sedangkan manual 37,1 detik. Untuk transaksi 3 buku dengan aplikasi $Q R$ Code perpustakaan adalah 14,7 detik sedangkan manual 1 menit 53,4 detik. Dan untuk transaksi 5 buku dengan aplikasi $Q R$ Code perpustakaan adalah 23,2 detik sedangkan manual 3 menit 43,4 detik. Berdasarkan hasil tersebut dinyatakan bahwa transaksi menggunakan aplikasi $Q R$ Code perpustakaan lebih efisien waktu.

\section{KESIMPULAN}

Berdasarkan penelitian yang dilakukan, aplikasi $Q R$ Code perpustakaan yang dirancang hanya berfokus pada transaksi peminjaman maupun pengembalian buku perpustakaan. Metode pengembangan system yang dilakukan menggunakan model waterfall. Dihasilkan tiga 3 alur utama, yakni alur saat user membuka aplikasi, alur saat user melakukan scan $Q R$ Code dan alur peminjaman dan pengembalian buku. Terdapat empat tabel yang digunakan untuk menyusun aplikasi $Q R$ Code Perpustakaan. Dihasilkan tampilan antar muka aplikasi mulai dari peminjaman dan pengembalian buku oleh user serta operasi transaksi yang dilakukan oleh petugas perpustakaan.

Dalam uji coba aplikasi dibuktikan bahwa transaksi menggunakan aplikasi $Q R$ Code perpustakaan berbasis android lebih cepat daripada manual. Lama waktu rata-rata transaksi untuk 1, 3 dan 5 buku dengan aplikasi $Q R$ Code perpustakaan masing-masing adalah 4,9 detik, 14,7 detik dan 23,2 detik. Sedangkan lama waktu rata-rata transaksi untuk 1, 3 dan 5 buku dengan transaksi manual masingmasing adalah 37,1 detik, 1 menit 53,4 detik dan 3 menit 43,4 detik.

Aplikasi QR Code berbasis Android yang diuji coba pada perpustakaan AKN Putra Sang Fajar Blitar masih banyak kekurangan. Diantaranya yakni perlu penambahan batas jumlah buku, sehingga buku yang dipinjam bisa lebih dari 2 buku. Kemudian juga diperlukan batas waktu pengembalian buku, bisa berupa timer untuk mengingatkan user untuk segera mengembalikan buku sebelum batas akhir. Disamping itu perlu fitur pencarian buku agar peminjam tahu apakah buku yang akan dipinjam masih tersedia sekaligus dapat menginformasikan buku-buku yang tersedia di perpustakaan. Juga diperlukan perbaikan basis data agar 
mampu menampung buku dengan jumlah yang banyak. Perbaikan-perbaikan dan penambahan fitur lain untuk menunjang kehandalan aplikasi ini juga mutlak diperlukan, sehingga dapat membantu petugas maupun peminjam buku di perpustakaan AKN Putra Sang Fajar hingga lebih baik lagi.

\section{REFERENSI}

[1] Undang-Undang Republik Indonesia No 43 Tahun 2007 tentang perpustakaan.

[2] P. G. Naik, R. S. Kamath, M. S. S. Jamsandekar, M. K. S. Mahajan, and M. M. B. Patil, "Enhancing the usability of library system at CSIBER using QR code," IOSR J. Comput. Eng., vol. 17, no. 1, pp. 2278-2661, 2015.

[3] W. Rahaman, "Enhancing library services using barcode, Qr code and rfid technology: a case study in Central library national institute of technology, Rourkela," Int. J. Digit. Libr.
Serv., vol. 6, no. 3, pp. 39-50, 2016

[4] L. Parabhoi, N. Bhattacharjya, and R. Dhar, "Use of QR Code in Library," in Applications of Modern Tools and Technology in Library Services, 2017, pp. 237-243.

[5] D. Sinaga, Mengelola perpustakaan sekolah. Bandung: Bejana, 2011.

[6] S. Muchyidin, Perpustakaan. Bandung: PT Puri Pustaka, 2008.

[7] K. H. Pandya and H. J. Galiyawala, "A Survey on QR Codes: in context of Research and Application," Int. J. Emerg. Technol. Adv. Eng., vol. 4, no. 3, pp. 258-262, 2014.

[8] M. Burton, Android App Development For Dummies. John Wiley \& Sons, 2015.

[9] A. Buchori, P. Setyosari, I. W. Dasna, and S. Ulfa, "Mobile Augmented Reality Media Design with Waterfall Model for Learning Geometry in College," Int. J. Appl. Eng. Res., vol. 12, no. 13, pp. 3773-3780, 2017. 